\title{
PENCEMARAN SAMPAH YANG BERDAMPAK TERHADAP KEHIDUPAN MASYARAKAT SEKITAR SUNGAI
}

\author{
Nurkamilah
}

Email:2010128220017@mhs.ulm.ac.id

Program Studi Pendidikan IPS Fakultas Keguruan dan Ilmu Pendidikan

Universitas Lambung Mangkurat

Banjarmasin

\begin{abstract}
Air merupakan sumber kehidupan di muka bumi ini, kita semua bergantung pada air. Untuk itu diperlukan air yang dapat dipergunakan sebagaimana mestinya. Tapi pada akhirakhir ini, persoalan penyediaan air yang memenuhi syarat menjadi masalah seluruh umat manusia. Dari segi kualitas dan kuantitas air telah berkurang yang disebabkan oleh pencemaran. Artikel ini membahas mengenai pencemaran air yang ditinjau dari sumber pencemaran, dampak serta penanggulangan pencemaran tersebut. Selain itu juga dijelaskan mengenai indikator pencemaran air dan pengertian pencemaran air. Diharapkan artikel ini dapat memberikan informasi untuk kita semиa, sehingga akan dapat mengurangi pencemaran yang terjadi dan akan didapat air yang aman, bersih dan sehat. Jenis penelitian yang digunakan adalah studi literatur. Metode studi literatur adalah serangkaian kegiatan yang berkenaan dengan metode pengumpulan data pustaka, membaca dan mencatat, serta mengelolah bahan penelitian. Dari hasil penelitan disebutkan bahwa sampah merupakan penyebab terjadinya pencemaran sungai, dan banyak faktor penyebab lainnya juga seperti pembuangan limbah.
\end{abstract}

Kata Kunci: kehidupan, Pencemaran sungai, limbah sampah, masyarakat 


\section{PENDAHULUAN}

Salah satu kebutuhan yang paling penting dikehidupan manusia tentu nya air. Menurut Kodoatie (2008) "air merupakan segala sumber bagi sebuah kehidupan. Tentunya semua makhluk membutuhkan air, serta menggunakan air untuk kepentingan kehidupan, sedangkan Indonesia banyak memiliki perairan yang melimpah serta Negara kepulauannya. Namun, disayangkan masih banyak masyarakat yang belum dapat memanfaatkan air dengan baik.

Bagi Indonesia sendiri, aliran masih sangat dibutuhkan untuk kehidupan sehari-hari. Berbeda dengan negara-negara maju, aliran ini dimanfaatkan sebagai tempat wisata di kota. Sungai dimanfaatkan untuk mencuci, dimanfaatkan untuk tempat pembuangan sampah, bahkan di daerah tertentu sungai dimanfaatkan untuk air minum dan masak.

Aliran adalah bagian masyarakat yang tidak jelas. Jalur air telah menjadi perkembangan mendasar ruang sejak zaman kuno di bidang perdagangan dan transportasi. Tragisnya, nasib saluran air di jaringan metropolitan tidak benar terbentuk. Sebagian besar sampah yang tidak diolah menumpuk dan dibuang di sembarang tempat, ke sungai dan lainlain. Sistem air berubah menjadi tempat pembuangan sampah goliath yang membuat banyak sungai menjadi dangkal. Ini karena tidak ada pengalaman dengan orang yang benar-benar membuang sampah ke sungai.

Adanya sampah yang dibuang ke sungai akan menimbulkan berbagai akibat yang merugikan seperti berkembangnya berbagai penyakit, tersumbatnya aliran sungai, pencemaran air dan tanah, pendangkalan saluran air, dll. Selanjutnya, masalah sampah telah diarahkan oleh otoritas publik, salah satunya yang diatur dalam UU no. 18 tahun 2008 tentang Penatausahaan Sampah. Terlepas dari potensi aktivitas pelayaran melalui perairan sungai, pemanfaatan sungai oleh warga sekitar sungau tidak hanya terkait dengan pemenuhan kebutuhan fisiologis semata (Subiyakto \& Mutiani, 2019).

Dengan adanya tempat sampah dapat digambarkan sebagai suatu usaha atau pembangunan yang menguasai ukuran TPA, menata, memindahkan dan mengirimkan, menggunakan kembali dan membuang sampah dengan mempertimbangkan komponen bantuan pemerintah, ekonomi, rencana, jaminan alam, gaya, dan pertimbangan lingkungan lainnya. Sedangkan menurut Undang-Undang Republik Indonesia Nomor 18 Tahun 2008, pengelolaan 
sampah rumah tangga terdiri atas pengurangan sampah dan penanganan sampah.

Kondisi ini sangat meresahkan, dimana hal ini disebabkan karena tidak adanya keakraban dengan masyarakat yang tinggal di sekitar sungai yang justru membuang sampah ke saluran air sehingga saluran air tersebut saat ini tidak dapat dimanfaatkan dan anehnya hal ini masih berlangsung hingga saat ini. Sampah yang dibawa bukan hanya sampah biasa, melainkan juga sampah anorganik. Takaran sampah yang dihasilkan harus dijaga dengan baik agar tidak menimbulkan dampak yang tidak ramah, misalnya mencemari lingkungan yang dapat mempengaruhi bantuan pemerintah, banjir, tersumbatnya saluran drainase, dan lain sebagainya pertimbangan mengenai sahnya pengolahan sampah di sekitarnya. masih belum kritis, hal ini terlihat dari singularitas sampah yang asli. Banyak orang percaya bahwa sampah adalah barang tambahan yang saat ini tidak berguna dan harus dibuang. Maka dari itu tujuan penulisan artikel ini adalah agar dapat mengetahui faktor penyebab terjadinya pencemarahan sungai, dan cara mengatasi permasalahan pencemaran ini.

\section{METODE}

Dalam artikel penelitian ini yang digunakan adalah studi literatur. Metode studi literatur adalah serangkaian kegiatan yang berkenaan dengan metode pengumpulan data pustaka, membaca dan mencatat, serta mengelolah bahan penelitian. Teknik ini dilakukan dengan tujuan untuk mengungkapkan berbagai teori-teori yang relevan dengan permasalahan yang sedang dihadapi/diteliti sebagai bahan rujukan dalam pembahasan hasil penelitian. Pengertian Lain tentang Studi literatur adalah mencari referensi teori yang relefan dengan kasus atau permasalahan yang ditemukan. Secara Umum Studi Literatur adalah cara untuk menyelesaikan

persoalan faktor penyebab terjadinya pencemaran sungai dengan menelusuri sumber-sumber tulisan yang pernah dibuat sebelumnya. 


\section{PEMBAHASAN}

Sampah adalah bahan sisa yang tidak diinginkan setelah terjadinya suatu siklus. Sampah adalah pemikiran buatan manusia, dalam siklus normal tidak ada pemborosan, hanya hal-hal yang berani. Tempat sampah ada di setiap periode ketidaknyamanan: padat, cair, atau gas. Ketika disebarluaskan dalam dua fase terakhir, khususnya gas, limbah dapat dianggap sebagai pelepasan. Pencurahan umumnya dihubungkan dengan polusi. Dalam kehidupan manusia, berton-ton sampah berasal dari kegiatan saat ini (atau sekitar itu disebut pemborosan), seperti penambangan, pengumpulan, dan penggunaan. Pada dasarnya semua barang dagangan canggih pada akhirnya akan dilepaskan, dengan ukuran pemborosan yang sebagian besar setara dengan penggunaan.

Pengertian sampah menurut SNI 13-1990-F tentang Tata Cara Pengelolaan Teknik Sampah Perkotaan didefinisikan sebagai limbah yang bersifat padat, terdiri dari zat organik dan zat anorganik yang dianggap tidak berguna lagi dan harus dikelola agar tidak membahayakan lingkungan dan melindungi investasi pembangunan. Menurut Undang-Undang Republik Indonesia Nomor 18 Tahun 2008 tentang Pengelolaan Sampah, sampah adalah sisa kegiatan sehari-hari manusia dan atau proses alam yang berbentuk padat (Depkes RI, 2008). Menurut Undang-Undang Republik Indonesia Nomor 18 Tahun 2008 tentang Pengelolaan Sampah, sampah adalah sisa kegiatan sehari-hari manusia dan atau proses alam yang berbentuk padat (Depkes RI, 2008).

Sampah adalah bahan limbah padat dari kegiatan keluarga, pasar, tempat kerja, rumah tinggal, penginapan, kafe, perusahaan, bahan bangunan flotsam dan jetsam serta bahan sisa yang digunakan untuk mesin kendaraan. Sampah merupakan efek samping dari latihan manusia yang selama ini dimanfaatkan (Sucipto, 2012). Setiap pergerakan manusia harus mengantarkan sampah atau sampah. Jumlah atau volume sampah sesuai dengan tingkat pemanfaatan produk atau bahan yang digunakan setiap hari (Sejati, 2009).

Sampah menurut WHO (World Health Organization), sampah merupakan suatu materi yang tidak digunakan, tidak terpakai, tidak disenangi, atau sesuatu yang dibuang yang berasal dari kegiatan manusia. Menurut undang-undang Republik Indonesia Nomor 18 Tahun 2008 sampah adalah sisa kegiatan seharihari manusia dan/atau proses alam yang berbentuk padat. 
Limbah yang dihasilkan oleh persiapan manusia dapat diminta berdasarkan beberapa model termasuk awal, pengaturan, struktur, wilayah, asosiasi waktu, sifat dan jenis. Dilihat dari tahap awal, pemborosan diatur berdasarkan tempat penciptaan, misalnya pemborosan keluarga, pemborosan mekanis, pemborosan perdagangan asing, seperti tempat usaha, dan sebagainya. Demikian pula, permintaan pemborosan juga dapat didasarkan pada potonganpotongan sampah yang dibuat. Penggambaran sampah ini dipisahkan menjadi dua kelompok, yaitu sampah khusus yang dihasilkan dari kegiatan-kegiatan tertentu yang memiliki keterkaitan yang sebanding, misalnya sampah kantor yang menghasilkan berton-ton sampah seperti kertas, karton dan semacamnya. Untuk sementara, pemilahan sampah lainnya adalah sampah campuran, di mana ada rencana sampah yang berbeda dicampur menjadi satu kegiatan tertentu, misalnya pemborosan pasar.

Tempat sampah juga dirancang berdasarkan bentuk, wilayah, misalnya sampah kota dan sampah provinsi, dilihat dari perjalanan waktu, jenis dan polanya. Penggambaran sampah berdasarkan kemiringannya dibedakan menjadi dua, yaitu sampah biasa, sebagai sampah yang dapat terurai atau rusak dengan baik dengan bantuan mikroorganisme, dan sampah anorganik, sebagai sampah yang tidak dapat dirusak oleh makhluk hidup sehingga sulit membusuk.

Seperti yang dikemukakan oleh Sejati (2009) pemborosan dibagi menjadi tiga kelompok, yaitu: 1) Sampah organik atau basah, sampah basah adalah sampah yang berasal dari makhluk hidup, seperti dedaunan, sampah dapur, sampah kafe, sampah sayur, hasil alam. memboroskan. Limbah semacam ini dapat rusak (busuk atau musnah) secara normal. 2) Sampah anorganik atau kering, sampah kering akan menjadi sampah yang tidak dapat diurai secara normal. Misalnya: logam, besi, toples, plastik, karet, botol, kaca. 3) Limbah B3, jenis limbah ini merusak manusia. Misalnya: baterai, jarum bekas, senyawa berbahaya, limbah atom. Sampah jenis ini membutuhkan penanganan yang luar biasa.

Sesuai dengan Undang-Undang Republik Indonesia Nomor 18 Tahun 2008 tentang Pengelolaan Sampah, jenis sampah yang diawasi meliputi: 1) Pemborosan rumah tangga, pemborosan mulai dari kegiatan sehari-hari dalam keluarga, kecuali tinja dan sampah sembarangan. 2) Sampah sejenis, pemborosan keluarga mulai dari kawasan bisnis, kawasan modern, kawasan unik, kantor sosial, kantor publik, atau kantor yang berpotensi berbeda. 3) Limbah spesifik, limbah yang mengandung B3, limbah B3, limbah yang muncul dari bencana, 
limbah perusak bangunan, limbah yang tidak dapat ditangani secara inovatif serta limbah yang tidak sesekali muncul. 4) Sampah Komersial, dihamburkan mulai dari kegiatan usaha seperti bidang usaha, pertokoan, rumah makan, pengaturan pengalihan, perumahan, studio dan stand. Demikian pula dari tempat-tempat seperti kantor, tempat sekolah, tempat cinta dan yayasan non-bisnis lainnya. 5) Sampah Bangunan Sampah mulai dari latihan perbaikan meliputi reklamasi dan penghancuran struktur seperti beton, kayu, balok dan ubin.

6) Sampah Fasilitas Umum Sampah ini berasal dari pembersihan dan pembersihan jalan, trotoar, taman, lapangan, daerah pengalihan dan kantor-kantor umum lainnya. Modelnya adalah daun, ranting, kertas kado, plastik dan residu.

Ada banyak sumber sampah, khususnya: 1) Rumah tangga, pada umumnya terdiri dari sampah alam dan anorganik, yang dihasilkan dari kegiatan keluarga. Misalnya, dari sampah dapur, pembibitan, sisa makanan, dan peralatan keluarga. 2) Kawasan komersial, khususnya sampah yang dihasilkan dari toko, rumah makan, pasar, tempat kerja, penginapan, dan lain- lain, biasanya terdiri dari bahan pembungkus sisa makanan., kertas, dll. 3) Limbah institusi berasal dari sekolah, klinik kesehatan, dan fokus pemerintah. 4) Limbah industri, mulai dari tindakan pembuatan secara mekanis, mulai dari penanganan bahan mentah hingga hasil pembuatan. 5) Sampah dari kantor-kantor umum, dari tempat rekreasi, pantai laut atau daerah hiburan. 6) Sampah dari sisa-sisa pembangunan gedung, tepatnya, menghambur-hamburkan mulai dari sisasisa pembangunan gedung, perbaikan, perusakan jalan, perluasan, dan lain- lain. 7) Sampah dari pemborosan air para eksekutif dan pembuangan sampah dari insinerator. 8) Limbah pertanian berasal dari sisa hortikultura yang saat ini tidak dapat dimanfaatkan (Damanhuri, 2010).

Dalam pengelolaan sebuah sampah adalah hal kegiatan yang dibuang ke pembuangan akhir. Dalam pengelolaan sampah itu sendiri secara garis besar ialah: pengendalian dalam timbulan sampah dari pengumpulan hingga ke pengangkutan sampai ke pengolahan dan TPA (Sejati, 2004). Perlu kita ketahui dalam pengelolaan sampah yang paling penting ada lima langkah. Kelima perspektif ini jelas terkait satu sama lain dan membentuk satu kesatuan, sehingga upaya untuk lebih mendorong pengelolaan sampah harus menggabungkan berbagai sistem. Sebanding dengan sudut pandang ini, khususnya: sudut kelembagaan, pembiayaan, aturan, usaha lokal, dan strategi praktis. 
Dalam Undang-Undang Nomor 18 Tahun 2008 yang berisi pemborosan, yang merupakan langkah prinsip dalam penyelenggaraan organisasi persampahan, khususnya dalam hal organisasi. Contoh pengelolaan sampah harus dibuat dengan persiapan tambahan agar sampah dapat dijadikan sebuah asset yang bias dimanfaatkan tentunya pada tingkat local hingga tempat pembuangan akhir, demikian sampah tersebut akan turun kedalam tanah yang terbatas.

Dengan melihat sifat dan desainnya, sampah dapat memberikan keuntungan finansial, misalnya jika diolah menjadi kompos dan bahan yang dimanfaatkan. Meskipun demikian, potensi nilai moneter ini harus ditemukan dengan cara yang tepat dan dipusatkan pada norma sehingga sistem yang dipilih dapat masuk akal secara finansial. Ditinjau dari asosiasi sampah, sebagian besar sampah yang ada di Indonesia adalah sampah biasa atau disebut juga sampah biasa. Sampah disebut normal karena jaringan metropolitan yang sangat besar dapat mencapai $70 \%$ dari total sampah, dan sekitar $28 \%$ adalah sampah non-alam yang menjadi objek persiapan vs, dari mata air yang hilang ke TPA. Sisa $2 \%$ memiliki nama yang berbeda, misalnya B3 yang harus diperiksa secara bebas. Sampah dengan kandungan zat bawaan yang tinggi ini sangat cocok untuk diolah menjadi kompos, sumber biogas dan lain sebagainya. Untuk sementara, bagian anorganik berpotensi sebagai bahan yang dapat digunakan kembali, seperti plastik, kertas, logam/wadah, kaca, fleksibel.

Melihat kenyataan ini, ada baiknya jika pengurangan takaran sampah dilakukan melalui upaya pengelolaan sampah yang terkoordinasi. Pengembangan kerangka kerja limbah yang kuat dan ekstensif, dan membutuhkan modal awal yang besar, juga membutuhkan kemampuan otoritas utilitarian yang besar. Untuk memahami penjelasan ini, asosiasi yang berharga antara wilayah bisnis dan asosiasi dengan individu daerah potensial dan berpengalaman dapat dibingkai. Dukungan afiliasi dapat membantu metode paling terkenal untuk melengkapi tempat kerja dan perusahaan dengan tingkat organisasi yang lebih luas dan meningkatkan gagasan organisasi mereka. Struktur otoritatif yang dibuat harus berhubungan dan membutuhkan penawaran dan sifat pemborosan serta contoh perubahan di kemudian hari. Sistem pengelolaan sampah harus diubah sesuai dengan sifat (waste moving quality) yang selama ini dianggap sebagai sampah yang sia-sia, mengalihkan nilainya menjadi bahan kritis ketika ditangani menjadi kompos dan bahan yang digunakan kembali dan digunakan. 
Sesuai Undang-Undang Nomor 18 Tahun 2008 tentang Penatausahaan Sampah, pengurus pemborosan dipisahkan menjadi dua prinsip pengumpulan, yaitu: Pertama, minimisasi sampah, yang terdiri dari pembatasan kejadian sampah, penggunaan kembali, dan penggunaan kembali. Kedua, penanganan pemborosan, yang terdiri dari: 1) Pemilahan: mengumpulkan dan memisahkan sampah sesuai dengan jenis, jumlah, atau potensi sifat sampah. 2) Pengumpulan: pemilahan dan pemindahan sampah dari sumber pemborosan ke tempat-tempat suci yang tidak permanen atau tempat tujuan penyiapan sampah yang terkoordinasi. 3) Transportasi: mengangkut sampah dari sumbernya maupun dari tujuan pemilahan sampah singkat atau dari tempat penyiapan sampah yang terkoordinasi ke tempat penanganan terakhir. 4) Pengolahan: mengubah atribut, organisasi, dan ukuran pemborosan.

5) Penanganan akhir limbah: pengembalian limbah dan tambahan penumpukan dari penyiapan sebelumnya ke media alam secara aman.

\section{SIMPULAN}

Sampah adalah bahan sisa yang tidak diinginkan setelah terwujudnya suatu kerjasama. Sampah adalah pemikiran buatan manusia, dalam siklus normal tidak ada pemborosan, hanya hal-hal yang berlangsung cukup lama. Sehingga semakin banyak sampah yang ditampung maka semakin banyak pula penyakit yang terdapat pada sampah tersebut sehingga dapat mengganggu kesejahteraan penghuni dan menyebabkan lingkungan tempat tinggal menjadi tidak normal. Pencemaran sungai yang terjadi di saluran air telah mencapai ukuran yang mengecewakan dan pertimbangan serta latihan dari berbagai sumber sangat diperlukan. Komunitas lokal berperan besar dalam upaya perubahan aliran, spesialis publik atau LSM sebagai pelopor atau penggerak, pertimbangan harus datang dari lingkungan untuk menjaga efisiensi dan kemungkinan aliran dapat diselidiki di antara mereka. lingkungan. Akhir-akhir ini, berbagai upaya telah dilakukan, para penulis menerima bahwa hadiah sebagai kemajuan besar lainnya dalam artikel ini dapat menjadi signifikan bagi pekerjaan untuk menghidupkan kembali aliran ini di kemudian hari. Salurannya sangat kotor, jadi pola kebangkitannya tidak akan semudah membalikkan telapak tangan. Siklus panjang harus dilalui dan membutuhkan minat, semua setara, perhatian utama untuk keadaan saat ini adalah semangat yang harus terus menyala sampai saluran air dibangun kembali dan menjadi teladan, mengingat kebutuhan lingkungan sekitar dijamin sekali. 


\section{DAFTAR PUSTAKA}

Arisanty, D., Adyatma, S., \& Huda, N. (2017). Analisis kandungan bakteri fecal coliform pada Sungai Kuin Kota Banjarmasin. Majalah Geografi Indonesia, 31(2), 51-60.

Andana, B., Arisanty, D., \& Adyatma, S. (2016). Evaluasi daya tampung sistem drainase di kecamatan banjarmasin selatan. Evaluasi Daya Tampung Sistem Drainase Di Kecamatan Banjarmasin Selatan.

Arisanty, D. (2017). Dampak Bencana Banjir Terhadap Kondisi Sosial Ekonomi masyarakat di Kecamatan Batu Benawa Kabupaten Hulu Sungai Tengah, Kalimantan Selatan. JPG (Jurnal Pendidikan Geografi), 4(4), 42-52.

Arisanty, D. (2020). Studi Efektifitas Bank Sampah Sebagai Salah Satu Pendekatan dalam Pengelolaan Sampah Tingkat Sekolah Menengah Atas (SMA) di Banjarmasin. JPG (Jurnal Pendidikan Geografi), 3(5), 22-37.

Ps, T. P. (2008). Penanganan dan pengolahan sampah. Penebar Swadaya Grup

Sampah, S. Pengertian Sampah.

Subekti, S. (2010). Pengelolaan Sampah Rumah Tangga 3R Berbasis Masyarakat. Prosiding SNST Fakultas Teknik, 1(1).

Subiyakto, B., Abbas, E. W., Arisanty, D., Mutiani, M., \& Akmal, H. (2020). Sungai dan Kehidupan Masyarakat Banjar: Penguatan Lokalitas dalam Wacana Pendidikan IPS yang Responsif.

Sudrajat, H. R. (2006). Mengelola sampah kota. Niaga Swadaya. 